American Journal of Applied Sciences 6 (5): 1004-1009, 2009

ISSN 1546-9239

(C) 2009 Science Publications

\title{
Preliminary Study of Phylogenetic Relationship of Rice Field Chironomidae (Diptera) Inferred From DNA Sequences of Mitochondrial Cytochrome Oxidase Subunit I
}

\author{
Salman A. Al-Shami, M.N. Siti Azizah, Che Salmah Md Rawi and Abu Hassan Ahmad \\ School of Biological Sciences, University Sains Malaysia, 11800 Penang, Malaysia
}

\begin{abstract}
Problem statement: Chironomidae have been recorded in rice fields throughout the world including in many countries such as India, Australia and the USA. Although some studies provide the key to genera level and note the difficulty of identifying the larvae to species level. Chironomid researches have been hindered because of difficulties in specimen preparation, identification, morphology and literature. Systematics, phylogenetics and taxonomic studies of insects developed quickly with emergence of molecular techniques. These techniques provide an effective tool toward more accurate identification of ambiguous chironomid species. Approach: Samples of chironomids larvae were collected from rice plots at Bukit Merah Agricultural Experimental Station (BMAES), Penang, Malaysia. A 710 bp fragment of mitochondrial gene Cytochrome Oxidase subunit I (COI) was amplified and sequenced. Results: Five species of Chironomidae; three species of subfamily Chironominae, Chironomus kiiensis, Polypedilum trigonus, Tanytarsus formosanus, two species of subfamily Tanypodinae, Clinotanypus sp and Tanypus punctipennis were morphologically identified. The phylogenetic relationship among these species was been investigated. High sequence divergence was observed between two individuals of the presumed $C$. kiiensis and it is suggested that more than one species may be present. However the intraspecific sequence divergence was lower between the other species of Tanypodinae subfamily. Interestingly, Tanytarsus formosanus showed close phylogenetic relationship to Tanypodinae species and this presumably reflect co-evolutionary traits of different subfamilies. Conclusion: The sequence of the mtDNA cytochrome oxidase subunit I gene has proven useful to investigate the phylogenetic relationship among the ambiguous species of chironomids.
\end{abstract}

Key words: Chironomidae, DNA sequencing, cytochrome oxidase subunit I

\section{INTRODUCTION}

Chironomidae is considered a species-rich family of flies, with almost 15000 species described worldwide $^{[1]}$. Generally, Chironomidae larvae are inhabitants of organically enriched places such as in flowing water of streams and rivers or standing water of lakes and pools as well as temporary rain-pools. As an important component of the aquatic insect community, Chironomidae has proven useful as biological indicators because of their sensitivity to chemical changes in aquatic ecosystems ${ }^{[2]}$. Therefore, they are often included in most ecological and toxicological studies $^{[3]}$ and to assess the environment in many lentic environments $s^{[4]}$.

Rice fields cover almost 70 million hectares in Southeast Asia. In Malaysia, rice is the third most important economic crop covering an area of about $209300 \mathrm{~h}^{[5]}$. They are considered a very important aquatic ecosystem not only as commercial resources but also as a biotic resource especially as wetland habitats ${ }^{[6]}$. Tropical rice fields are diverse in insect fauna, which serve as an important food source for fishes ${ }^{[6,7]}$.

Chironomidae have been recorded in rice fields throughout the world including in many countries such as India, Australia and the USA ${ }^{[8]}$. However, in the Malaysian peninsula, very little is known about the distribution, taxonomy and systematics of rice field chironomids.

Although some studies ${ }^{[9]}$ have provided useful keys up to genera level there are difficulties of identifying the larvae to species level. Chironomid research have been shunned typically by many benthologists because of perceived difficulties in specimen preparation, identification, morphology and literature ${ }^{[10,11]}$. The systematics, phylogenetics and taxonomic studies of insects have however developed quickly with the

Corresponding Author: M.N. Siti Azizah, School of Biological Sciences, University Sains Malaysia, 11800 Penang, Malaysia Tel: +6046534004 Fax: +6046565125 
emergence of molecular techniques. These techniques provide an effective tool toward more accurate identification of ambiguous chironomid species ${ }^{[11-16]}$. In most molecular studies the mitochondrial DNA (mtDNA) is used and often only one or several genes can act as an effective marker such as cytochrome Oxidase Subunit one (COI). This gene has been widely used in evolutionary studies, population genetics, as well as in species identification due to its relatively high degree of variation ${ }^{[11,16]}$

The DNA sequencing of mitochondrial Cytochrome Oxidase b $(\mathrm{COb})$ has been reported for the non-biting midge, $C$. calligraphus in addition to studies on morphological and karyological identification ${ }^{[4]}$. In another study two mitochondrial genes, Cytochrome b (Cytb) and Cytochrome Oxidase subunit I (COI), were utilized as phylogenetic markers in an investigation of chironomid species $^{[12]}$. These two genes were chosen because they are the largest mtDNA protein coding genes and have been found to be informative in phylogenetic studies conducted on other insects. The nucleotide sequence of a 685 bp Cytb and 596 bp COI segments were determined for 36 Chironomus species from the Holarctic and Australasia. The phylogenetic relationship was successfully deduced based on the concatenated sequence of $1281 \mathrm{bp}$ from both genes.

Perhaps, the most intensive study of Chironomus was the study on species identification and distribution in the Holarctic region ${ }^{[13]}$. DNA sequences from the mitochondrial Cytochrome b and cytochrome oxidase subunit I genes and a nuclear gene (globin 2b) were investigated in this study. The sequences were used as tools for investigation of Nearctic and Palearctic populations of Chironomus species which were distinguished to be $C$. biwaprimus, $C$. pallidivittatus, $C$. tentans and $C$. dilutus. Similarly, the partial segment of $\mathrm{COI}$ and $\mathrm{Cytb}$ genes were used as phylogenetic markers for the study on Sergentia (Chironomidae: Diptera) ${ }^{[15]}$. The concatenated (1241 bp) sequence from the two genes was successfully used to infer phylogenetic relationships among seven Sergentia species.

In Malaysia, there is no documentation of any investigation on the molecular structure and phylogenetic relationships among the chironomid species either in lentic or lotic environments. Therefore the aim of this study was to investigate the systematic and phylogenetic relationship among rice field chironomid species inferred from the sequence of mtDNA COI gene. This study will contribute towards the presently limited knowledge on this group in Peninsular Malaysia.

\section{MATERIALS AND METHODS}

Larvae sampling and sorting: Chironomidae larvae were sampled from the rice fields of Bukit Merah Agricultural Experimental Station (BMAES), Penang, Malaysia at latitude $5.417^{\circ} \mathrm{N}$ and longitude $100.417^{\circ} \mathrm{E}$. The samples were collected using a long handle aquatic net with $15 \times 15 \mathrm{~cm}$ frame and $30 \mathrm{~cm}$ long net of approximately $300 \mu \mathrm{m}$ mesh size ${ }^{[17]}$. The sediment sample was washed in a sieve with a mesh size of $300 \mu \mathrm{m}$ and transferred into a white plastic basin filled with water. The larvae were sorted and preserved in $80 \%$ ethanol. Chironomid slides were prepared following routine procedures ${ }^{[18]}$. The prepared slides were identified using several keys ${ }^{[9,18-20]}$.

DNA extraction, amplification and sequencing: The chironomid samples were preserved in alcohol prior to DNA extraction. Two individuals of Chironomus kiiensis, Polypedilum trigonus, Tanypus punctipennis and one individual of Tanytarsus formosanus and Clinotanypus sp were analysed. The total genomic DNA was extracted using the EZ-10 spin Column Blood Genomic DNA minipreps kit. The DNA extracted was then subjected to PCR amplification. The PCR profile was adapted from Sharley et al. ${ }^{[16]}$. The PCR reaction contained 10X PCR buffer, $1.5 \mathrm{mM}$ $\mathrm{MgCl}_{2}, 0.2 \mathrm{mM}$ dNTPs, $0.5 \mu \mathrm{L}$ of each primer 911 and 912 (Table 1) ${ }^{[12]}, \quad 0.5 \mu \mathrm{L}$ Taq DNA polymerase (Promega), $5 \mu \mathrm{L}$ DNA template and $\mathrm{H}_{2} \mathrm{O}$ to $50 \mu \mathrm{L}$. The thermal program was made up of an initial predenaturation step at $94^{\circ} \mathrm{C}$ for $3 \mathrm{~min}$, followed by 35 cycles consisting of a denaturation step at $94^{\circ} \mathrm{C}$ for $30 \mathrm{sec}$, annealing step at $45^{\circ} \mathrm{C}$ for $30 \mathrm{sec}$ and an extension step at $72^{\circ} \mathrm{C}$ for $1 \mathrm{~min}$. The final extension step was at $72^{\circ} \mathrm{C}$ for $5 \mathrm{~min}$. The PCR products were placed in a refrigerator at $4^{\circ} \mathrm{C}$ for storage. Then PCR products were analyzed by horizontal electrophoresis on a $1.7 \%$ agarose gel in $0.5 \mathrm{X}$ TBE buffer.

The PCR products obtained were purified using QIAquick PCR Purification kit. The fragment was sequenced automatically in both directions conducted using Big Dye Termiunator Cycle Sequencing Kit. The outgroup sequence Culicoides chiopterus with Accession number AM236750 (472 bp) and Anopheles stephensi with Accession number DQ154166 (684 bp)

Table 1: Sequence of primers 911 and 912 from 5'-3' end

\begin{tabular}{ll}
\hline Name of primer & Sequence \\
\hline 911 (Forward) & 5'-TTAACTTCAGGGTGACCA \\
& AAAAATCA--3' \\
912 (Reverse) & 5'--TTACTACCAATCATA AAG \\
& ATATTG G--3' \\
\hline
\end{tabular}


were chosen from GenBank. DNA sequences were analysed using the computer software package program DNASIS Version 3.2. The mtDNA COI gene sequences obtained were aligned using CLUSTALX $^{[21]}$ software (version 1.83) to obtain the consensus sequence of mtDNA by multiple alignments of the forward and reverse sequences. Generation of phylogenetic tree was carried out using PAUP software (version $4.1 \mathrm{~b}$ ).

\section{RESULTS}

The larvae of five chironomid taxa belonging to subfamilies Chironominae (tribes Chironomini and Tanytarsini) and Tanypodinae were identified from the rice field at BMAES based on morphological characters. The species were identified as Chironomus kiiensis Tokunaga, Polypedilum trigonus Edwards, Tanytarsus formosanus Kieffer (Chironominae), Clinotanypus sp and Tanypus punctipennis Meigen (Tanypodinae).

An approximately $710 \mathrm{bp}$ region of mtDNA Cytochrome Oxidase subunit I (COI) gene was successfully PCR amplified using primers 911 and $912^{[12]}$. This amplified partial region of the mtDNA Cytochrome Oxidase subunit I (COI) gene was then sequenced and aligned. The intraspecific genetic distance based on the Maximum Parsimony (MP) analysis $^{[22]}$ of the Chironomidae species was 0.201 within Chironomus and 0.118 within Polypedilum. However, in the subfamily Tanypodinae it was only 0.002 between the two individuals of Tanypus (Table 2). The phylogenetic tree was best described with tree Length (L) of 1170 steps, a Consistency Index (CI) of 0.8347, Homoplasy Index (HI) of 0.1653 , Retention Index (RI) of 0.8806, Rescaled Consistency index (RC) of 0.7489, parsimony- informative characters of 536 and parsimonyuninformative characters of 79 . The topology of the rooted tree consisted of three distinct clusters comprising of the outgroup and two chironomid clusters (Fig. 1).

The chironomid species were divided into two major clusters. The first major cluster divided into two subclusters, the first subcluster grouped the duplicate sequences of $C$. kiiensis (Chironominae). The second subcluster grouped a polyphyletic clade of $T$. formosanus and Clinotanypus sp as sister groups to the monophyletic group comprising of Tp. punctipennis. The second major cluster is the monophyletic clade grouping $P$. trigonus which form the basal group for the other clusters. All branches were very well supported by high bootstrap values apart from the Tp. punctipennis clade which had slightly lower (but acceptable) values of $70 \%$.

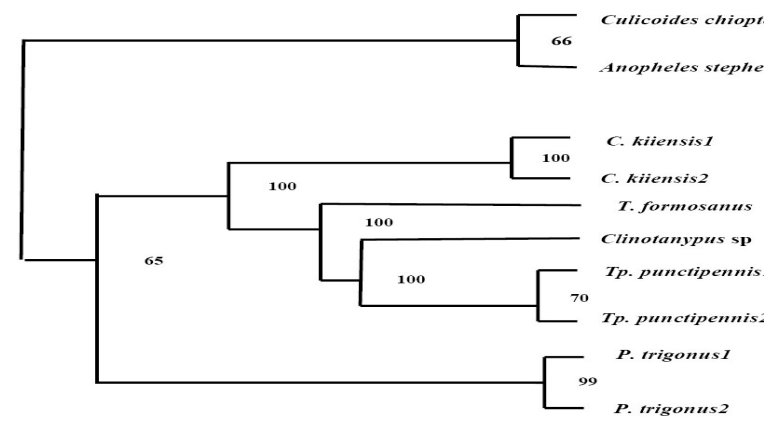

Fig. 1: Maximum Parsimony (MP) tree inferred from partial mitochondrial COI gene sequence data from five species of Chironomidae. Bootstrap values are based on 1000 replications. Trees are rooted with outgroups Culicoides chiopterus and Anopheles stephensi

Table 2: Intra and Interspecies genetic distance (MP) of chironomidae species deduced from the partial sequence of COI mtDNA gene for chironomidae species, chironomus kiiensis, polypedilum trigonus, tanytarsus formosanus, clinotanypus $\mathrm{sp}$ and tanypus punctipennis collected from rice fields at BMAES with outgroups Culicoides chiopterus and Anopheles stephensi

\begin{tabular}{|c|c|c|c|c|c|c|c|c|c|}
\hline & $\begin{array}{l}\text { Culicoides } \\
\text { chiopterus }\end{array}$ & $\begin{array}{c}\text { Anopheles } \\
\text { stephensi }\end{array}$ & $\begin{array}{l}\text { Chironomus } \\
\text { kiiensis1 }\end{array}$ & $\begin{array}{l}\text { Chironomus } \\
\text { kiiensis2 }\end{array}$ & $\begin{array}{l}\text { Polypedilum } \\
\text { trigonus } 1\end{array}$ & $\begin{array}{l}\text { Polypedilum } \\
\text { trigonus } 2\end{array}$ & $\begin{array}{l}\text { Tanytarsus } \\
\text { formosanus }\end{array}$ & $\begin{array}{l}\text { Tanypus } \\
\text { punctipennis } 1\end{array}$ & $\begin{array}{l}\text { Tanypus } \\
\text { punctipennis2 }\end{array}$ \\
\hline Culicoides chiopterus & 0 & & & & & & & & \\
\hline Anopheles stephensi & 0.396 & 0 & & & & & & & \\
\hline Chironomus kiiensis 1 & 0.485 & 0.524 & 0 & & & & & & \\
\hline Chironomus kiiensis 2 & 0.685 & 0.674 & 0.201 & 0 & & & & & \\
\hline Polypedilum trigonus1 & 0.241 & 0.277 & 0.669 & 0.695 & 0 & & & & \\
\hline Polypedilum trigonus 2 & 0.211 & 0.241 & 0.668 & 0.688 & 0.118 & 0 & & & \\
\hline Tanytarsus formosanus & 0.633 & 0.592 & 0.538 & 0.560 & 0.625 & 0.610 & 0 & & \\
\hline Tanypus punctipennis 1 & 0.636 & 0.600 & 0.561 & 0.563 & 0.630 & 0.618 & 0.177 & 0 & \\
\hline Tanypus punctipennis 2 & 0.637 & 0.595 & 0.551 & 0.559 & 0.627 & 0.618 & 0.173 & 0.002 & 0 \\
\hline Clinotanypus sp & 0.633 & 0.598 & 0.550 & 0.564 & 0.626 & 0.614 & 0.177 & 0.015 & 0.013 \\
\hline
\end{tabular}




\section{DISCUSSION}

Five species belonging to two subfamilies were identified from the BMAES rice field in Penang, Peninsular Malaysia. These included three species of subfamily Chironominae, C. kiiensis, which has also been reported from Korean rice paddies ${ }^{[23]}, P$. trigonus, one of the common genera in tropical waters including those of Borne ${ }^{[9]}$ and Tanytarsus. formosanus which is very widely distributedincluding in some areas in Southeast Asia such as Sumatra and Thailand ${ }^{[24]}$. Our study also documented two species of subfamily Tanypodinae; Clinotanypus sp and Tp. punctipennis from this rice field. Tanypus punctipennis has also been reported from the warm shallow pools with high nutrient loadings in Sumatra ${ }^{[9]}$.

The potential of mtDNA region, specifically the COI gene, in chironomid identification was investigated. The use of mtDNA sequence for chironomid identification has been recognized as a useful tool to resolve the problems of morphological identification $\left.^{[11,} 16\right]$. Moreover, the application of mtDNA, particularly the COI and Cytb genes, in inferring the phylogeny and genetic divergence of chironomid species have been investigated by several groups $^{[12,25]}$ with the conclusion that the mtDNA COI gene can be used effectively to investigate the phylogenetic relationship among the chironomid species.

The preliminary results of genetic variation presented here showed that the mt COI gene had high variation among different chironomid species belonging to the two subfamilies, Chironominae and Tanypodinae with divergence level above 0.5 except for $T$. formosanus, (0.17). In this study, the inferred phylogenetic tree based on a partial fragment of mt COI gene within chironomid species was investigated. This isRepeat of results and of next para.

The results showed the monophyletic nature of individuals identified to their species or sibling species based on conventional keys, i.e. all individuals of the presumed $C$. kiiensis and $P$. trigonus. were grouped into their own clusters showing the effectiveness of this DNA technique in species identification. The sequence alignment strongly suggests that $P$. trigonus and $T p$. punctipennis had been accurately identified to the species level with low genetic distance values. However, the much higher sequence divergence observed between the two presumed C. kiiensis specimens would indicate that might be more than one species involved. A comparison of these sequence data with those of $C$. kiiensis obtained from Japan also revealed fairly moderate divergence, inconsistent with intraspecies relationship (Jon Martin, University of Melbourne, personal communication). Further taxonomic investigation is certainly warranted to elucidate the taxonomic status of this taxon. Thus, the DNA method has proven useful in identifying chironomid during certain life stages and offers a reliable and rapid approach for routine identifications of ambiguous species or individuals. The produced cladogram was in general agreement with previous hypothesis based on morphological characters with $C$. kiiensis and $P$. trigonus forming outgroup taxa to the Tanypodinae subfamily.

In an attempt to summarise distinguishing morphological characters for each taxon and to investigate any correlation with molecular data, a summary of morphological keys is tabulated. Table 3 shows the matrix of the combined morphological keys ${ }^{[9,18]}$ to the subfamilies and genera of Chironomidae using 15 morphological characters. Characters 4,6 are synapomorphic in Chironominae while they are absent in Tanypodinae. On the other hand 12,13 appeared to be synapomorphic characters in Tanypodinae. This would suggest that the presence of characters 4,6 is ancestral to its absence while the opposite is true for characters 12,13. Within the Chironominae, C. kiiensis is distinguished by the derived morphological characters 7 and 11, while characters 9 and 10 distinguished $T$. formosanus. These characters are specific for the genus but not shared within this subfamily. Similarly, characters 14 and 15 are synapomorphic for Clinotanypus sp but not for the Tanypodinae subfamily. Interestingly $T$. formosanus formed a sister taxon within the clade grouping the Tanypodinae subfamily forming a highly supported cluster in the MP phylogenetic tree with 100\% bootstrap support. There is an obvious and plausible explanation for this incongruence. Tanytarsus formosanus is known for its small size and the identification using morphological criteria has been reported to be unreliable and problematical particularly during early life stages ${ }^{[24]}$. Due to the lack of other supporting data as well as the exclusion of many species within these two subfamilies, it is premature to suggest a revision of $T$. formosanus. Inspection of Table 3 shows character 8 (presence of posterior parapods) is shared by $T$. formosanus, $P$. trigonus and $C$. kiiensis with the subfamily Tanypodinae. It would be interesting to investigate whether other species within Chironomidae that are more closely related based on molecular data also exhibit this character. This might indicate the evolutionary history of this character. 
Am. J. Applied Sci., 6 (5): 1004-1009, 2009

Table 3: A summary of combined taxonomic key of Epler, $2001^{[18]}$ to the subfamilies and species (genera) of Chironomidae collected from BMAES, Penang, Malaysia.

\begin{tabular}{|c|c|c|c|c|c|c|}
\hline \multirow[b]{2}{*}{ No } & \multirow[b]{2}{*}{$\begin{array}{l}\text { Taxonomic } \\
\text { Character }\end{array}$} & \multicolumn{3}{|c|}{ Chironominae } & \multicolumn{2}{|c|}{ Tanypodinae } \\
\hline & & $\begin{array}{l}\text { Chironomus } \\
\text { kiiensis }\end{array}$ & $\begin{array}{l}\text { Polypedilum } \\
\text { trigonus }\end{array}$ & $\begin{array}{l}\text { Tanytarsus } \\
\text { formosanus }\end{array}$ & $\begin{array}{l}\text { Clinotanypus } \\
\mathrm{sp}\end{array}$ & $\begin{array}{l}\text { Tanypus } \\
\text { punctipennis }\end{array}$ \\
\hline 1. & Mean body length (mm) & $13.1(n=41)$ & $4.8(\mathrm{n}=18)$ & $5.2(n=22)$ & $10.6(n=7)$ & $6.3(n=14)$ \\
\hline 2. & Head capsule shape & Rounded & Rounded & Rounded & Triangular & $\begin{array}{l}\text { Oval to } \\
\text { Triangular }\end{array}$ \\
\hline 3. & Body pigmentation & Dark red & Dark red & Pale to dark red & Pale red & Dark red \\
\hline 4. & Antennae with 5-8 segments & + & + & + & - & - \\
\hline 5. & Striated ventromental plate & + & + & + & - & - \\
\hline 6. & SI plumose & + & + & + & - & - \\
\hline 7. & $\begin{array}{l}\text { Ventral tubules on XI } \\
\text { abdominal segment }\end{array}$ & + & - & - & - & - \\
\hline 8. & Posterior parapods present & + & + & + & + & + \\
\hline 9. & Long pedestal & - & - & + & - & - \\
\hline 10. & Apical lauterborn organ & - & - & + & - & - \\
\hline 11. & Odd number of mentum teeth & + & - & - & - & - \\
\hline 12. & Retractile antennae & - & - & - & + & + \\
\hline 13. & Ligula present & - & - & - & + & + \\
\hline 14. & Even number of ligula teeth & - & - & - & + & - \\
\hline 15. & Long apical tooth of mandible & - & - & - & + & - \\
\hline
\end{tabular}

\section{CONCLUSION}

The COI mtDNA gene has proven useful in precise identification of chironomids of recognized species. Although molecular methods are easy to apply considerable DNA data is required covering as many member species for a reliable phylogenetic relationships. In Southeast Asia, there is insufficient molecular data of Chironomidae compared to the molecular data of the Holarctic region. It is recommended to apply the molecular techniques in further investigations on the aquatic insects especially Chironomidae from different habitats in Malaysia.

\section{ACKNOWLEDGEMENT}

The authors are grateful to the Agricultural Department of Sebrang Perai Penang, for allowing us to use their rice plots at Bukit Merah for this study. Thanks are due to Universiti Sains Malaysia (USM) for providing vehicles to the study site. The great help in accurate chironomid identification by Prof. Wang (Nankai University, China), Prof. Ole A. Saether, Prof. Trond Andersen and Dr. Humberto Mendes (Bergen University, Norway) is highly appreciated. Sincere thanks go to Dr. Jon Martin (Melbourne University, Australia) for his valuable comments about $\mathrm{C}$. kiiensis taxonomic status and helpful remarks on the draft of this manuscript. This research was funded by USM short term research grant No 304/PBIOLOGI/635047.

\section{REFERENCES}

1. Cranston, P.S., 1995. Introduction. In: The Chironomidae: Biology and Ecology of Non-Biting Midges, Armitage, P.D., P.S. Cranston and L.C.V. Pinder (Eds.). Chapman and Hall, London, United Kingdom, pp: 1-10. http://entomology.ucdavis.edu/gullanandcranstonlab /ArmitageCh1.pdf

2. Dudley, W. and W.F. Blair, 1992. Aquatic Insects. 1st Edn., CAB International Wallington Oxon, UK., ISBN: 0-85198-782-6, pp: 358.

3. Boothroyd, I.K.G. 1995. Temporal and Deil Drift of Chironomidae (Diptera: Insecta) Larvae in a Northern Newzeland Streams. The Chironomidae: Biology and Ecology of Non-Biting Midges, Armitage, P.D., P.S. Cranston and L.C.V. Pinder (Eds.). Chapman and Hall, London, United Kingdom, ISBN: 0-643-056564, pp: 213-223.

4. Pfenninger, M., C. Nowak, C. Kley, D. Steinke and B. Streit, 2007. Utility of DNA taxonomy and barcoding for the inference of larval community structure in morphologically cryptic Chironomus (Diptera) species. Mol. Ecol., 16: 1957-1968. DOI: 10.1111/j.1365-294X.2006.03136.x

5. Karim, S.M.R., M. Azmi and B.S. Ismail, 2004. Weed problems and their management in rice fields of Malaysia -An over view. Weed Biol. Manage., 4: 177-186. DOI: $10.1111 / \mathrm{j} .1445-$ 6664.2004.00136.x 
6. Che Salmah, M.R., S.T.S Hassan, A. Abu Hassan and A.B. Ali, 1998. Influencing of physical and chemical factors on the larval abundance of Neurothemis tullia (Drudy) (Odonata: Libellulidae) in a rain fed rice field. Hydrobioogia, 389: 193-202. DOI: $10.1023 / \mathrm{A}: 1003511227253$

7. Ali, A.B. and M. Ahmad, 1988. Water quality in rice field and sump Ponds and its relationship to phytoplankton growth in rice field fish culture system. Trop. Ecol., 29: 63-70. http://md1.csa.com/partners/viewrecord.php?reque ster $=$ gs\&collection=ENV\&recid $=3944886$.

8. Stevens, M.M., 1995. Biology and Control of Chironomus tepperi Skuse, A Pest of Rice in New South Wales. In: The Chironomidae: Biology and Ecology of Non-biting Midges, Armitage, P.D., P.S. Cranston and L.C.V. Pinder (Eds.). Chapman and Hall, United Kingdom, London, ISBN: 0-643056564, pp: 235-239.

9. Cranston, P.S., 2004. Chironomidae, In: The Freshwater Invertebrates of Malaysia and Singapore, C.M. Yule and H.S. Yong (Eds.). Academy of Sciences, Malaysia, pp: 711-735. http://entomology.ucdavis.edu/chiropage/seAsiank ey.pdf

10. Bishop, J.E., 1973. Limnology of a small Malayan river Sungai Gombak. Dr. W. Junk BV., Netherlands, ISBN: 13: 978-9061930747.

11. Carew, M.E., V. Pettigrove and A.A. Hoffmann, 2003. Identify chironomids (Diptera) for biological monitoring with PCR-RFLP. Bull. Entomol. Res., 93: 483-490. DOI: 10.1079/BER2003268

12. Guryev, V., I. Makarevitch, A. Blinov and J. Martin, 2001. Phylogeny of the genus Chironomus (diptera) inferred from DNA sequences of mitochondrial cytochrome $\mathrm{B}$ and cytochrome oxidase I. Mol. Phylogenet. Evol., 19: 9-21. DOI: 10.1006/mpev.2001.0898

13. Martin, J., V. Guryev and A. Blinov, 2002. Population variability in Chironomus (Comaptochironomus) species (diptera, nematocera) with a Holarctic distribution: Evidence of mitochondrial gene flow. Insect Mol. Biol., 11: 387-397. DOI: 10.1046/j.13652583.2002.00348.x

14. Spies, M., J.E. Sublette, M.F. Sublette, W. Wulker, J. Martin, A. Hille, M.A. Miller and K. Witt, 2002. Pan-America Chironomus calligraphus Goeldi, 1905 (Diptera: Chironomidae): Species or complex? Evidence from external morphology, karyology and DNA sequencing. Aquat. Insect., 24: 91-113. DOI: 10.1076/aqin.24.2.91.4900
15. Papoucheva, E., V. Proviz, C. Lambkin, B. Goddeeris and A. Blinov, 2003. Phylogeny of the endemic Baiklian Sergentia (Chironomidae: Diptera). Mol. Phylogenet. Evol., 29: 120-125. DOI: $10.1016 / \mathrm{S} 1055-7903(03) 00075-7$

16. Sharley, D.J., V. Pettigrove and Y.M. Parson, 2004. Molecular Identification of Chironomus spp. (Diptera) for biomonitoring of aquatic ecosystems. Aus. J. Entomol., 43: 359-365. DOI: 10.1111/j.1440-6055.2004.00417.x

17. Storey, A.W. and L.C.V. Pinder, 1985. Mesh-size and efficiency of sampling of larval chironomidae. Hydrobiologia, 124: 193-197. DOI: 10.1007/BF00015235.

18. Epler, J.H., 2001. Identification manual for the larval Chironomidae (Diptera) of North and South Carolina. Special Publication SJ2001-SP13. http://www.home.earthlink.net/ johnepler/pubs.html

19. Morse, J.C., Y. Lianfang and T. Lixin, 1994. Aquatic insect of China Useful for Monitoring Water Quality. 1st Edn., Hohai University Press, Nanjing, ISBN: 7-5630-0240-5, pp: 570.

20. Merritt, R.W. and K.W. Cummins, 1996. An introduction to the aquatic insect of North America, 3rd Edn., Kenndall/Hunt Publication Co., ISBN: 978-0-7575-5049-2, pp: 862.

21. Thompson, J.D., T.J. Gibson, F. Plewniak, F. Jeanmougin and D.G. Higgins, 1997. The ClustalX windows interface: Flexible strategies for multiple sequence alignment aided by quality analysis tools. Nucl. Acids Res., 24: 4876-4882. http://www.ncbi.nlm.nih.gov/pubmed/9396791

22. Faris, J.S., 1970. Methods for computing wagner trees. Syst. Zool., 18: 374-385.

23. Jeong, K.Y., H.Y. Yum, I.Y. Lee, H.L. Ree, C.S. Hong, D.S. Kim and T.S. Yong, 2004. Molecular cloning and characterization of tropomyosin, a major allergen of Chironomus kiiensis, a dominant species of nonbiting midges in Korea. Clin. Diagnostic Lab. Immunol., 11: 320-324. DOI:10.1128/CDLI.11.2.320-324.2004

24. Ekrem, T., 2002. A review of selected South and East Asian Tanytarsus v.d. Wulp (Diptera: Chironomidae). Hydrobiologia, 474: 1-39. DOI: 10.1023/A:1016527603086

25. Allegrucci, G., G.Carchini, V. Todisco, P. Convey and V. Sbordoni, 2005. A molecular phylogeny of Antarctic Chironomidae and its implications for biogeographical history. Polar Biol., 29: 320-326. DOI: $10.1007 / \mathrm{s} 00300-005-0056-7$ 